Bond University

Research Repository

\title{
The state of primary-care research
}

Mant, D; Del Mar, C; Glasziou, P; Knottnerus, A; Wallace, P; van Weel, C

Published in:

The Lancet

DOI:

10.1016/S0140-6736(04)17027-X

Licence:

CC BY-NC-ND

Link to output in Bond University research repository.

Recommended citation(APA):

Mant, D., Del Mar, C., Glasziou, P., Knottnerus, A., Wallace, P., \& van Weel, C. (2004). The state of primarycare research. The Lancet, 364(9438), 1004-1006. https://doi.org/10.1016/S0140-6736(04)17027-X

\section{General rights}

Copyright and moral rights for the publications made accessible in the public portal are retained by the authors and/or other copyright owners and it is a condition of accessing publications that users recognise and abide by the legal requirements associated with these rights.

For more information, or if you believe that this document breaches copyright, please contact the Bond University research repository coordinator. 


\title{
The State Of Primary-Care Research
}

\author{
David Mant, Chris Del Mar, Paul Glasziou, Andre Knottnerus, Paul Wallace and Chris Van Weel
}

\section{Correspondence to:}

Prof David Mant, Department of Primary Health Care, Oxford University, Old Road Campus, Oxford OX2 7EY, UK

david.mant@dphpc.ox.ac.uk

\begin{abstract}
In March, 2003, the editor of The Lancet attended an international conference in Kingston, Ontario, Canada, on primary-care research, subsequently running a rather dyspeptic editorial entitled "Is primary-care research a lost cause?" ${ }^{1}$ This article highlighted the unacceptable weakness of primary-care research worldwide. A particular concern of the conference was the shortage of primary care research in less economically developed countries to inform the clinical and public health management of malnutrition, malaria, AIDS, water-borne infection, and other illnesses of poverty. ${ }^{2}$ However, problems exist even in economically developed countries. In Australia, for example, a crude measure of research productivity with practising physicians as the denominator suggests that primary care is only $1 \%$ as productive as internal medicine, $0.5 \%$ as productive as public health and $1.6 \%$ as productive as surgery. ${ }^{3}$ But for The Lancet to characterise primary-care research as a "lost cause" is unhelpful. This notion implies either that the field is so weak that it cannot be resuscitated or that it is irrelevant anyway. Both are wrong.
\end{abstract}

\section{Primary care needs an evidence base}

Research in primary care is essential because: (1) clinical and preventive care must be underpinned by research evidence; (2) the bulk of such care in most countries, especially poorer countries, is delivered in primary care; and (3) evidence to underpin this care (for example, the diagnosis and appropriate management of headache, vomiting, rashes, diarrhoea, fever, joint pains, chest pain, abdominal pain, cough, breathlessness, vaginal bleeding-the list is long and ranges across all specialist areas) cannot be informed by laboratory and hospital-based research alone. ${ }^{4}$ Absence of research in primary care will lead to over-investigation, inappropriate treatment, and diagnostic delay through wrongtrack referral. For example, it was estimated in 1994 that the implementation in primary care of the National Institutes of Health consensus guidelines on the management of headache would add US\$2 billion to the annual US health budget; similarly, the shortage of an adequate evidence base for the use of antibiotics in primary care was estimated to cost at least $\$ 50$ million a year in the USA and to contribute to the global problem of antibiotic resistance. ${ }^{5}$ 


\section{Primary-care research should focus on clinical practice}

The Lancet editorial suggested that the focus of primary care research should be the family. This is a serious misunderstanding. The main function of primary-care research is to inform clinical practice in primary care. A government review in the UK characterised the research need in terms of four "evidence gaps"-about the effectiveness of interventions delivered mainly in primary care, the applicability of hospital-based research to primary care, the implementation of best evidence in primary-care practice, and the basic science of illness and its care in the community. ${ }^{6}$ Similarly, the Dutch government has commissioned a specific national research council programme to bridge the evidence gaps made apparent by the development of national guidelines for the management of common conditions in primary care, essential elements of which had to be based on opinion because of a lack of a rigorous research base. ${ }^{7-9}$

\section{Primary-care research can affect clinical practice}

These governmental decisions to support and develop primary-care research were affected by the observation that high-quality research that influences clinical practice can be done successfully in primary care. This is particularly clear in relation to the management of conditions seen only in primary care. For example, publication of the results of the first primary-care-based treatment trial of otitis media in children over 20 years ago ${ }^{10}$ revolutionised the clinical management of this disease in the Netherlands; the Cochrane review of subsequent general practice trials of antibiotic treatment of otitis media ${ }^{11}$ now provides the evidence base for clinical care of this condition internationally. The success of primary-care research is also especially clear in relation to disease prevention. For example, more than half the observed reduction in coronary heart disease mortality has been attributed to primary and secondary prevention, ${ }^{\mathbf{1 2}}$ and many of the clinical trials underpinning preventive care of this and other important public health problems were done in a primary-care setting. ${ }^{13-15}$ The primary-care-based Cochrane smoking addiction review group, which was stimulated by an early review done by researchers involved in the general practice smoking cessation trials ${ }^{\mathbf{1 6}}$ now provides the evidence-base that underpins governmental policy internationally. And primary care is an important player in the internationally important field of vaccine research. ${ }^{17}$

The effect of primary-care research on chronic disease is perhaps more difficult to tease out because applied clinical research also takes place in a hospital setting. However, a substantial number of important and clinically relevant trials and cohort studies have been published by primary-care based researchers in relation to all the common chronic conditions managed in primary care, including back pain, ${ }^{\mathbf{1 8}}$ asthma,${ }^{\mathbf{1 9}}$ cancer,${ }^{\mathbf{2 0}}$ heart failure, ${ }^{21}$ diabetes, ${ }^{22}$ and depression ${ }^{23}$ Primary care has taken a lead in developing the methodology of applied clinical research to assess the effectiveness of complex health service interventions. ${ }^{24,25}$ There are increasingly influential and important bodies of work being undertaken in relation to the diagnosis, monitoring, and long-term care of illness outside hospital. ${ }^{26,27}$ It was probably also relevant to the investment decision of the UK and Dutch governments that several universities in the UK and the Netherlands do primary-care research that is assessed as equating to the best attainable levels of 
international excellence in any discipline and compete on equal terms with all other medical science disciplines. ${ }^{28,29}$

\section{Achieving high quality primary-care research}

Achievement of excellence in clinical research depends above all on recruitment of the most able and committed people to the discipline. In many countries, primary care is still perceived as second class, ${ }^{\mathbf{3 0}}$ and the academic career structure in primary care is often notable for its financial and career insecurity. This problem will not be easily overcome without government intervention at a national level to address barriers to recruitment and retention, and this will not be a short-term fix. Once some of the brightest and best have been recruited, reaching the point of self-sustained growth in research still needs affirmative action by funding agencies. These agencies, including the non-governmental medical charities, need to divert just a small fraction of their resources to have a substantial effect. One strategy would be to develop primary-care expertise alongside existing centres of research excellence in other disciplines. However, it requires longterm funding of core staff, not just short-term project funding even if ring-fenced. Most primary-care researchers still do not have the core infrastructure funding and career security which underpins the accrual of high-level research expertise in a subject area and allows the development work that produces the highest quality grant applications.

\section{Achieving integration with clinical care}

High-quality applied clinical research requires integration of research into clinical services. Primary care is certainly not unique in this requirement-the freedom with which clinicians of all disciplines can make evidence-free clinical judgments contrasts starkly with the barriers to undertaking research to supply the evidence. ${ }^{31}$ For example, we can contribute to the global problem of antibiotic resistance by prescribing antibiotics for common viral infections without accountability or constraint, but the barriers to prescribing the drugs as part of a research study to address this problem are immense. Health-service managers are often short-sightedly intolerant of the increased clinic and consultation time required for research and informed consent. Governments need to make a strategic decision to embed research within a health-care system to allow primary-care research (and applied clinical research in hospitals) to take place. The pay-off from this investment is not simply the production of research evidence. Good, motivated primarycare clinicians in any health-care system want to reflect and improve on what they do (that is, to engage in research) and we believe that it is self-evident that encouraging this activity promotes the recruitment and retention of good doctors and stimulates the implementation of evidence-based best practice.

\section{Conclusion}

Primary-care research is not a lost cause. It is an important cause. Effective prevention in primary care avoids serious diseases. No disease can be cured unless someone, usually in primary care, first recognises it. No long-term treatment works unless it is administered effectively, again often in primary care. All these clinical activities need the leadership, 
reflection, and underpinning evidence that primary-care research provides. The strength of primary-care research in any country is probably a good indicator of the strength and quality of primary care in that country.

However, the weaknesses highlighted by The Lancet need to be taken seriously, especially in countries where primary care is all there is. Medical charities, as well as government agencies, could and should play a much stronger role. But above all it is incumbent on the researchers themselves to continue to show that they make a difference to the quality of care. Investment in research in primary care must be recognised not only as an investment in the generation of clinical evidence, but also an investment in clinical leadership and service quality.

\section{References}

1 The Lancet. Is primary-care research a lost cause? Lancet 2003; 361: 977.

2 van Weel C, Rosser WW. Improving health care globally: a critical review of the necessity of family medicine research and recommendations to build research capacity. Annals Family Med 2004;2 (suppl 2):5-16.

3 Askew DA, Glasziou PP, Del Mar CB. Research output of Australian general practice: a comparison with medicine, surgery and public health. Med J Aust 2001; 175: 77-80.

$4 \mathbf{R} \& D$ in primary care: national working group report. London: UK Department of Health, 1997.

5 Green L, Hames C, Nutting P. Potential of practice-based research networks: experiences from ASPN. J Family Practice 1994; 38: 400-07.

6 NHS R\&D Strategic review: primary care. Report of Topic Working Group. London: UK Department of Health, 1999.

7 Grol R, Grimshaw J. From best evidence to best practice: effective implementation of change in patients' care. Lancet 2003; 362: 1225-30.

8 Tasche M, Oosterberg E, Kolnaar B, Rosmalen K. Inventarisatie van lacunes in huisartsgeneeskundige kennis. HuisartsWet 2001; 44: 91-95.

9 Netherlands Organisation for Health Research and Development: English Introduction. http://zonmw.collexis.net/index.asp?s=4535 (accessed Aug 5, 2004).

10 van Buchem FL, Dunk JH, van't Hof MA. Therapy of acute otitis media: myringotomy, antibiotics, or neither? A double-blind study in children. Lancet 1981; 2: 883-87.

11 Del Mar C, Glasziou P, Hayem M. Are antibiotics indicated as initial treatment for children with acute otitis media? A meta-analysis. BMJ 1997; 314: 1526-29.

12 Capewell S, Beaglehome R, Seddon M, McMurray J. Explanation for the decline in coronary heart disease mortality rates in Auckland New Zealand between 1982 and 1993. Circulation 2000; 102: 1511-16. 
13 Collaborative Group of the Primary Prevention Project. Low-dose aspirin and vitamin $\mathrm{E}$ in people at cardiovascular risk: a randomised trial in general practice. Lancet 2001; 357: 89-95.

14 British Family Heart Study Group. Randomised controlled trial evaluating cardiovascular screening and intervention in general practice: principal results. BMJ 1994; 308: 313-20.

15 Wallace P, Cutler SF, Haines A. Randomised controlled trial of general practitioner intervention in patients with excessive alcohol consumption. BMJ 1988; 297: 663-68.

16 Silagy C, Mant D, Fowler G, Lodge M. Meta-analysis on efficacy of nicotine replacement therapies in smoking cessation. Lancet 1994; 343: 139-42.

17 Govaert TM, Thijs CT, Masurel N, Sprenger MJ, Dinant GJ, Knottnerus JA. The efficacy of influenza vaccination in elderly individuals. A randomized double-blind placebo-controlled trial. JAMA 1994; 272: 1661-65.

18 Kendrick D, Fielding K, Bentley E, Kerslake R, Miller P, Pringle M. Radiography of the lumbar spine in primary care patients with low back pain: randomised controlled trial. BMJ 2001; 322: 400-05.

19 van Schayck CP, Dompeling E, van Herwaarden CLA, et al. Bronchodilator treatment in moderate asthma or chronic bronchitis: continuous or on demand? A randomised controlled study. BMJ 1991; 303: 1426-31.

20 Grunfeld E, Mant D, Yudkin P, et al. Routine follow-up of breast cancer in primary care: a randomised trial. BMJ 1996: 313: 665-69.

21 Morgan S, Smith H, Simpson I, et al. Prevalence and clinical characteristics of left ventricular dysfunction among elderly patients in a general practice setting. BMJ 1999; 318: 368-71.

22 Kinmonth A-L, Woodcock A, Griffin S, Spiegal N, Campbell M. Randomised controlled trial of patient centred care of diabetes in general practice: impact on current wellbeing and future disease risk. BMJ 1998; 317:1202-08.

23 Thompson C, Kinmonth A-L, Stevens L, et al. Effects of a clinical-practice guideline and practice-based education on detection and outcome of depression in primary care: Hampshire Depression Project randomised controlled trial. Lancet 2000; 355: 185-91.

24 Bradley F, Wiles R, Kinmonth A, Mant D, Gantley M. Development and evaluation of complex interventions in health services research: case study of the Southampton heart integrated care project. BMJ 1999; 318: 711-15.

25 Roland M, Morris R. A study of the natural history of low-back pain: development of guidelines for trials of treatment in primary care. Spine 1983; 8:145-50.

26 Hopstaken RM, Muris JW, Knottnerus JA, Kester AD, Rinkens PE, Dinant GJ. Contributions of symptoms, signs, erythrocyte sedimentation rate, and C-reactive protein to a diagnosis of pneumonia in acute lower respiratory tract infection. BGJP 2003; 53: 358-64. 
27 Allen C, Glasziou P, Del Mar C. Bed rest: a potentially harmful treatment needing more careful evaluation. Lancet 1999; 354: 1229-33.

28 UK Higher Education Funding Councils. Research Assessment Exercise 2001: The outcome (RAE 2001/4). Bristol: RAE team, Northavon House, 2001. http://www. hero.ac.uk/rae (accessed Aug 5, 2004).

29 Netherlands School of Primary Care Research External evaluation 1999. http://www.researchschoolcare.nl/Inhoud/Report97-99/appendix8.htm (accessed Aug $5,2004)$.

30 Del Mar CB, Freeman GK, Van Weel C. "Only a GP?": is the solution to the general practice crisis intellectual? Med J Aust 2003; 179: 26-29.

31 Glasziou P, Chalmers I. Ethics review roulette: what can we learn? BMJ 2004; 328:121-22.

\section{Author Affiliations}

Department of Primary Health Care, Oxford University, Oxford, UK

(Prof D Mant FRCGP, P Glasziou FRACGP);

Netherlands School of Primary Care Research, University of Maastricht, Maastricht, Netherlands (A Knottnerus MD);

Department of Primary Care and Population Sciences, Royal Free and University College London Medical School, London, UK

(Prof P Wallace FRCGP);

Department of General Practice, University Medical Centre Nijmegen, Nijmegen, Netherlands (Prof C van Weel MD);

Faculty of Health Science and Medicine, Bond University, Queensland, Australia (Prof C Del Mar FRACGP)

\section{Contributors}

The thrust of this paper was agreed by informal discussion between all authors, including a telephone conference. D Mant drafted the original text; all authors contributed to three redrafts. All authors have read and agreed the final version submitted.

\section{Conflict of interest statement}

$\mathrm{C}$ van Weel was involved in the organisation of the Kingston Conference. We are all University funded academic researchers in primary care with an interest in promoting the discipline. 